\title{
Primitive neuroectodermal tumor of the cervix uteri
}

INSERM

\section{Source}

INSERM. (1999). Orphanet: an online rare disease and orphan drug data base. Primitive neuroectodermal tumor of the cervix uteri. ORPHA:213812

Primitive neuroectodermal tumor of the cervix uteri is a rare cancer of cervix uteri derived from neural crest cells, histologically composed of small, round neoplatic cells with variable degree of neural, glial and ependymal differentiation. Macroscopically, the tumor is often a large, soft, poorly circumscribed mass with infiltrative borders and necrotic areas. It presents with dysfuntional vag inal bleeding or discharge, lower abdominal pain and uterine enlargement. 